\title{
Higher Pedagogical Education for Sustainable Development in Russia and in France: A New Master's Degree Programs
}

\author{
Olga Ilina*, and Evgeniia Brazhnik \\ The Herzen State Pedagogical University of Russia, St. Petersburg, Russia
}

\begin{abstract}
Higher pedagogical education in Russia and France is currently undergoing modernization. In connection with the new challenges of time, global changes in the world community there is a growing public interest in the problems of sustainable development as the only possible way of civilization movement. Under these conditions, there is a need to improve teacher training, the inclusion of new training modules in the educational process, and the creation of new master's degree programs. This study aims to analyze the situation by introducing the idea of "education for sustainable development (ESD)" into the organization of higher teacher education, which is constantly reforming in the context of the Bologna process, on the example of two countries - Russia and France. The study identifies the main tendencies of pedagogical education modernization, examines the teacher training system in terms of ESD ideas, considers Master's programs in universities of Russia and France.
\end{abstract}

\section{Introduction}

The study of changes in university teacher education becomes relevant in the current period of internationalization and constant modernization of higher education in European countries. Teacher education is in search of a rethinking of the ideas and practices of humanistic and humanistic education in a changing world.

The source of constant change in higher education is the Bologna Process. As a result of the transformations in the context of the Bologna process undertaken in 2003-2021 in the Russian Federation, a transition was made to a two-level system of higher education (bachelor's and master's degrees) while maintaining the programs of a long training cycle (specialty) in several professional areas. In addition, the reform of postgraduate education into the third level of education (while retaining the opportunity to defend two levels of dissertation research - candidate of sciences and doctor of sciences) was implemented, a system of credits was introduced, and the number of joint international programs in higher education was increased. At the same time, Russia's participation in the Bologna process has certain difficulties, which are associated with established traditions, the desire to preserve national identity [1].

\footnotetext{
* Corresponding author: ol.ig.ilina@gmail.com
} 
In France, as well as in Russia, higher pedagogical education is being modernized; ways are being sought to develop lifelong pedagogical education to become a "learning French society". Even before the 1980s, France and Russia were characterized by a centralized system of higher education management [2]. The Bologna process has led to creating a decentralized system of university management, the autonomy of universities in France, the educational and cultural regional diversity of higher education institutions, the organization of internal and external evaluation of the quality of education.

The modern worldview is based on sustainable development (SD) of society, with education playing a key role. As a result of pedagogical activities in school education, teachers who influence the development of a student's personality, a citizen of their country, their worldview, and formation influence the development of a student's personality. In addition, the emergence of a variety of master's degree programs in education for sustainable development contributes to improving teacher education in today's context.

The purpose of this study is to identify general trends in the development of higher teacher education in Russia and France in the context of the ongoing Bologna process and introduction of ESD ideas into the educational process, to study their impact on the emergence of new Master's programs for teacher training.

\section{Materials and Methods}

The following methods were used in the study: comparative, problem-comparative analysis of research in the field of teacher education, historical-logical, hermeneutic, discourse analysis; method of systematization and classification based on the study of works by French and Russian researchers; generalization and synthesis; comparison of the results of theoretical analysis.

Theoretical prerequisites of the analysis are the concept of continuous pedagogical education as a flexible subsystem of education, which performs an anticipatory function concerning culture, science, to the entire education system, concerning the labor market.

The sources for the study were the declarations and official documents of the Bologna process, as well as reports, projects, reports of international organizations in the field of education. In addition, legislative acts, circulars, decrees of the French government, presidential decrees, ministerial reports and reports of national commissions and committees on education quality evaluation, normative pedagogical documentation were studied.

\section{Results and Discussion}

\subsection{Trends in the development of modern higher education in the context of the idea of sustainable development}

The concept of sustainable development (SD) implies a global policy framework aimed at strategic planning for the future in the interconnectedness of society and nature. Such a path is based on economic and social change as well as spiritual and practical values and orientations that should ensure "balanced consumption of resources and human use of the environment without threatening to deplete those resources in the future" [3].

The transition to SD begins with establishing education for sustainable development, which acts as one of the key tools to achieve the 17 global sustainable development goals adopted in 2015 in the "2030 Agenda for Sustainable Development". [4]. This raises new requirements for education: it is necessary not only to fill the content of education with new knowledge in the context of the concept of sustainable development but also to teach how to apply it in professional activities correctly. 
In addition, the higher education system is influenced by external socio-economic conditions and global trends that predetermine future development vectors. Table 1 . The list of the main trends in the development of university teacher education common to Russia and France is given with an indication of the substantive nature of these changes.

Table 1. Trends in the development of university teacher education in Russia and France.

\begin{tabular}{|c|c|}
\hline $\begin{array}{l}\text { Trends in the } \\
\text { professional training } \\
\text { of future teachers }\end{array}$ & Content of the changes \\
\hline $\begin{array}{c}\text { Fundamentalization of } \\
\text { education }\end{array}$ & 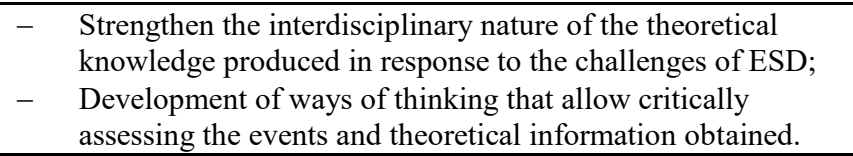 \\
\hline $\begin{array}{l}\text { Practice-oriented } \\
\text { education }\end{array}$ & $\begin{array}{ll} & \text { development of practices (dispersed and concentrated); } \\
- & \text { establishment of psycho-pedagogical laboratories; } \\
- & \text { involvement of students in volunteering socially and } \\
& \text { professionally significant activities. }\end{array}$ \\
\hline $\begin{array}{l}\text { Technologization of } \\
\text { education }\end{array}$ & $\begin{array}{l}\text { - } \\
\text { develop "service competencies" of students using information } \\
\text { technologies; } \\
\text { - } \\
\text { develop communication competencies during practical } \\
\text { classes and interactive lectures; } \\
\text { _ develop students' innovative activities by means of design. }\end{array}$ \\
\hline $\begin{array}{c}\text { Individualization, } \\
\text { variation of education }\end{array}$ & $\begin{array}{l}\text { - } \begin{array}{l}\text { Formation of individual learning trajectories according to the } \\
\text { requests of students and employers; }\end{array} \\
\text { - } \\
\text { variability of study assignments according to the student's } \\
\text { choice; } \\
\text { - }\end{array}$ \\
\hline Psychological education & $\begin{array}{ll}- & \text { development of "psychological" competencies, development } \\
\text { of emotional intelligence, empathy skills; } \\
\text { _ } \\
\text { development of reflexive skills. }\end{array}$ \\
\hline $\begin{array}{l}\text { Values in teacher } \\
\text { education }\end{array}$ & $\begin{array}{ll}- & \text { strengthening the importance of developing personal and } \\
& \text { value orientations of future teachers, } \\
-\quad & \text { moral development of the future teacher's personality; } \\
-\quad & \text { learning the value of the teaching profession. }\end{array}$ \\
\hline $\begin{array}{l}\text { developing leadership } \\
\text { skills }\end{array}$ & 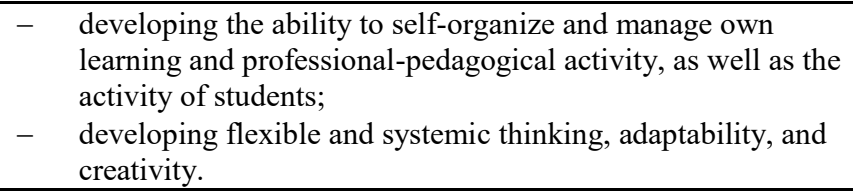 \\
\hline $\begin{array}{l}\text { Digitalization of } \\
\text { education }\end{array}$ & $\begin{array}{ll} & \text { developing of distance learning; } \\
- & \text { predominance of blended learning in universities; } \\
- & \text { developing individualized personalized learning; } \\
- & \text { increasing the number of education management systems and } \\
& \text { e-learning courses; } \\
-\quad & \text { transformation of the educational environment and transition } \\
& \text { to the virtual educational space; } \\
- & \text { transformation of the teacher's role, the need to develop new } \\
& \text { competencies (mentor, tutor, coordinator, etc.). }\end{array}$ \\
\hline
\end{tabular}

\subsection{Modernization of teacher education}




\subsubsection{Russian Federation}

Since Russia joined the Bologna process in 2003, a new generation of state educational standards for higher education in education for teachers has been developed, and the structure of university education for teachers has changed: the Bachelor's degree (5 years) and the Master's degree ( 2 years) have been introduced instead of the Specialist's degree (5 years). The development of an innovative educational environment in Russian pedagogical universities becomes a priority task. The main conditions for its creation are the innovative infrastructure of the pedagogical education system, new educational practices based on humanitarian technologies, implementation of the possibility to choose educational routes, forms, and content of professional-pedagogical education. A graduate of a higher teacher education system is prepared not only for professional activity in the role of a teacher but also for a much broader social activity. General professional training of students is designed to consider the complex nature of pedagogical work, the uncertainty of the current situation, the multifunctionality of the pedagogical activity, its emotional richness, etc. Professional competence includes a characteristic of professional training and students' education, the ability to solve vital tasks based on mastering general culture and social experience.

The leading principle of implementing Bachelor's degree programs in higher teacher education is student's self-determination in education and subsequent choice of professional self-realization. Such a specialist freely learns allied pedagogical specialties, is ready to change the sphere of activity, and continually improve qualification. The next level of pedagogical training - Master's education is coordinated with the Bachelor's programs of pedagogical direction. "The purpose of master's pedagogical education is operative personoriented training of a professional capable of solving innovative tasks related to the development of continuing education system" [5].

It should be noted that such form of education as a Master's degree, organized in connection with Russia's accession to the Bologna process, was essentially a renewal of the old Russian traditions in higher education, which existed in university education before the revolution of 1917.

Improvement of teacher training content in 2013-2015 was aimed at all content cycles in the educational program [6].

The main results of the modernization of higher pedagogical education in the Russian Federation since 2014 are strengthening of the practice-oriented educational process, the modular construction of educational programs, competency-based approach in education. A system to manage the modernization of teacher education was established - the Council for the Development of Continuing Teacher Education, the Federal Training and Methodological Association in the higher education system in the field of 44.00.00 "Education and Pedagogical Sciences". The resources for the internationalization of pedagogical education in the Russian Federation in the Bologna process have emerged. A new function of teacher education was preparing a teacher for professional intercultural interaction in education, for participation in international cooperation, and in international projects for the development of ESD [7].

Thus, organizational and pedagogical conditions, including the development of modular construction of learning content, master's pedagogical education, can contribute to implementing the idea of ESD in teacher education [8].

\subsubsection{France}

The strategy of modern education reforms in France aims to solve the following problems: adaptation of the education system to the new socio-economic development; equalization of students' opportunities following the norms of social justice; improving the quality of education; development of national and international standards. European integration trends 
of education development in France (mobility, standards, quality, transparency, international component in the content, international recognition of academic degrees and titles, etc.) are based on the internationalization strategy. This strategy is built in France on the foundation of state guarantees of equal opportunities and open access to all levels of education, continuity, humanization, and cultural appropriateness, i.e., following those fundamental principles of the educational system that reinforce national priorities and ensure the preservation of national and cultural identity while meeting the highest international educational standards" [9].

The traditional model of French university education, including short- and long-term specialist training programs, created the basis for the reform of French universities according to the LMD model (Licence, Master, Doctorat) in the context of the Bologna process.

In teacher education in France, as well as in the Russian Federation, during the Bologna process, the competence approach has spread, according to which "professional competence" is "the confirmation by an individual that he/she has those abilities, knowledge, skills, and practical skills that are necessary to perform professional activities following the requirements of the state and society" [10].

In France, pedagogy in higher education is transformed into sciences of education (sciences de l'éducation), which includes a wide range of disciplines: psychology, sociology, history, philosophy, philosophy of education, special pedagogy, etc. Thus, there is a transition from "normative pedagogy to scientific pedagogy", which provides future teachers with theoretical knowledge and skills of practical work with teaching staff [10].

The variability of professional-pedagogical training (full-time, blended learning; distance learning) is growing; in different universities, there is a variety of approaches to the selection and structuring of the content of professional-pedagogical training of students, with an emphasis on the educational function of professional training: the sociological orientation formation of "an active participant in social life" is increasing.

The domestic system of teacher education of particular interest is the multistage system of teacher education in France (pre-professional, trainee, and postgraduate stages of teacher training), application of individualized and personalized learning technologies, as well as various forms of improving professional training of teachers (coordinating council, tutoring, interdisciplinary teacher teams, professional training groups).

As in the Russian Federation, the development of continuous education in France includes building a learning society. The development of higher education in the modern period, including higher pedagogical education, is characterized by the transition to active pedagogy with the integration of new digital technologies in the educational process. The use of digital technologies should be systematic in teaching and assessing student achievement. It can foster collaborative activities, promote teamwork, encourage experimentation, and spread innovation. There is a shift from the role of the teacher imparting relatively fixed knowledge content to that of a teacher-guide or mentor who guides and accompanies each learner's progress, helping them achieve success.

Along with this, the leading change in the teacher's activity becomes the change in the culture of interaction in education, which is based on the principles of trust, free responsibility, benevolent mentoring, and cooperation [11].

In general, integration processes, development of international cooperation, mobility of students and scientific-pedagogical personnel, increase in the number of international projects in education, etc., are taking place in the education system of Russia and France. Table 2 presents a comparison of the results of changes in teacher education under the conditions of implementing the ideas of the Bologna Declaration. 
Table 2. Comparison of the results of changes in the organization of teacher education in the Russian Federation and in France in the context of the Bologna process.

\begin{tabular}{|c|c|c|}
\hline $\begin{array}{c}\text { Study } \\
\text { parameter }\end{array}$ & Russia & France \\
\hline $\begin{array}{l}\text { Legislative } \\
\text { documents }\end{array}$ & $\begin{array}{l}\text { - 24.10.2007 Federal Law "On } \\
\text { the introduction of } \\
\text { amendments to certain } \\
\text { legislative acts of the Russian } \\
\text { Federation (as concerns the } \\
\text { establishment of levels of } \\
\text { higher pedagogical } \\
\text { education)" (2007). } \\
\text { - Since 2011, a transition has } \\
\text { been made from the specialist } \\
\text { to the standards of the } \\
\text { bachelor's level (540600 } \\
\text { Pedagogy) - } 4 \text { years of study } \\
\text { (developed by the Herzen } \\
\text { Russian State Pedagogical } \\
\text { University). The standard of } \\
\text { "Education and Pedagogy" } \\
\text { training direction is a } \\
\text { Bachelor's degree with a 4- } \\
\text { year term of study and a 5- } \\
\text { year term of study (double- } \\
\text { discipline Bachelor's degree). } \\
\text { - 29.12.2012 Federal Law "On } \\
\text { Education in the Russian } \\
\text { Federation". } \\
\text { - The law reflects the } \\
\text { modernization and } \\
\text { internationalization of } \\
\text { education. }\end{array}$ & $\begin{array}{l}\text { - 15.06.2000 Education Code } \\
\text { - 08.04.2002 Law on changing the } \\
\text { architecture of higher education in } \\
\text { France. } \\
\text { - 23.04.2005 The Future School } \\
\text { Leadership and Program Act. The } \\
\text { law regulates the modernization of } \\
\text { education in France in the context } \\
\text { of globalization, approaching to all- } \\
\text { European standards of quality } \\
\text { education. } \\
\text { - 10.08.2007 Law on University } \\
\text { Autonomy. Major changes: the } \\
\text { transition, within the framework of } \\
\text { internationalization, from } \\
\text { centralized management by the } \\
\text { Ministry of Education to autonomy } \\
\text { of universities. } \\
\text { - 26.07.2019 Trust School Act. To } \\
\text { reorganize teacher training } \\
\text { institutes and to ensure the same } \\
\text { education for the teaching } \\
\text { profession throughout the country. }\end{array}$ \\
\hline $\begin{array}{c}\text { Types of } \\
\text { institutions } \\
\text { providing } \\
\text { teacher training. }\end{array}$ & $\begin{array}{l}\text { Federal Law "On Education in the } \\
\text { Russian Federation" No. 273-FZ } \\
\text { dated December 29, 2012 } \\
\text { (version dated July 23, 2013): } \\
\quad-\quad \text { federal universities; } \\
-\quad \text { pedagogical } \\
\quad \text { universities; } \\
-\quad \text { academies; } \\
-\quad \text { institutions; } \\
-\quad \text { colleges. }\end{array}$ & $\begin{array}{l}\text { Book VII of the Education Code } \\
\text { (2016 data): } \\
\text { - Public institutions of a scientific, } \\
\text { cultural, and professional nature; } \\
\text { - Teacher training institutions; } \\
\text { - Private universities; } \\
\text { - Administrative nature of the } \\
\text { universities; } \\
\text { - Specialized universities. }\end{array}$ \\
\hline $\begin{array}{l}\text { Content of } \\
\text { teacher } \\
\text { education }\end{array}$ & $\begin{array}{l}\text { Combination of scientific } \\
\text { fundamentals, practical psycho- } \\
\text { pedagogical training, and subject- } \\
\text { specific learning. }\end{array}$ & $\begin{array}{l}\text { General cultural, psychological and } \\
\text { pedagogical, professional, and } \\
\text { practical training. }\end{array}$ \\
\hline $\begin{array}{l}\text { Technology in } \\
\text { teacher } \\
\text { education }\end{array}$ & $\begin{array}{l}\text { Problem-based learning, debates, } \\
\text { and discussions, simulation, and } \\
\text { game methods, individual } \\
\text { learning trajectories, collective } \\
\text { creative activities, etc.) and the } \\
\text { potential of new information and } \\
\text { communication technologies, etc. }\end{array}$ & $\begin{array}{l}\text { Technologies of individualized, } \\
\text { personalized, problem-based learning, } \\
\text { tutoring system, small group learning, } \\
\text { etc. }\end{array}$ \\
\hline
\end{tabular}




\subsection{Education and teacher training for sustainable development in the Russian Federation and France}

New challenges of sustainable development need to be reflected in pedagogical practice, didactics, and philosophy of pedagogy in higher teacher education. Since the concept of SD is based on three components: ecology, economics, and socio-humanitarian knowledge, the content of ESD can be filled with integrated courses of interdisciplinary nature.

The essence of ESD is the complex formation of a value-based worldview of human existence in the interconnectedness of society and the individual. Therefore, in addition to incorporating meta- and interdisciplinarity in the learning process, students need to develop personal qualities, such as analytical, critical, and project thinking, reflection, forecasting, readiness to act, and live in fast-changing conditions, etc. Three approaches to selecting ESD content have been proposed [12]:

- The "enlightened" approach consists of incorporating information about the concept of sustainable development into education content in the form of modules or separate training courses;

- ESD approach as the current stage of development of environmental education;

- approach based on the interconnection of the three components of the SD concept: environmental, economic, and social sides in the practical implementation of the local level.

An example of an ESD "enlightened" approach in France is a specialized course. The University of Grenoble has included a course on "Problems of the Environment" (Problèmes environnementaux) in its foreign language vocational training. (Problèmes environnementaux).

French universities have opened various master's programs whose educational content is related to the SD concept. Thus, the University of Paris-Saclet organizes educational programs of Master's degree for the benefit of SD in different fields of study: "Agrotechnical, Environment, Territories, Nature, Forest", "Biodiversity", "Ecology and Evolution", "Integrative Biology and Physiology", "Biology and Health", "Law in Health", "Economics of Environment, Energy and Transport", "Research on Development and Environment", "Territory Management and Local Development".

A separate Master's program, the first-year Master's program (M1) "Sustainable Development" at the same university is dedicated to an interdisciplinary approach within the concept of SD. This program includes case studies in economics and other interdisciplinary studies (sociology, anthropology, methodology, natural science). Economics and other interdisciplinary studies are currently identified as the most promising areas for addressing collective action issues related to contemporary problems of inequality and pollution. Other master's programs have been established as part of the training of specialists in related fields of economics, ecology, and social sciences.

Of particular interest from the French experience is the new educational program of a teaching master's degree "Education in health and sustainable development: learning and mediation", for which enrolment has opened for the academic year 2021-2022 at the Jules Verne University of Picardy. The Master's program is implemented within the framework of the professions of teaching, education and training (Métiers de l'Enseignement, de l'Education et de la Formation) with a specialization in Educational Leadership (encadrement éducatif). The development of this Master's degree was a response to a social demand from school principals, local government officials to develop programs to foster responsibility, critical thinking, and an understanding of pressing social issues. In addition, there was a need for professional reorientation among students and educators to provide adolescents and youth with health, sustainable development, and patriotic programs. This Master's degree includes an academic and professional focus. The developers of this Master's program are teacherresearchers, instructors, and facilitators interested in integrating interdisciplinary knowledge in ESD. Various teaching technologies are used in the Master's program: discussions and 
debates, case method, subject mapping (graphic technology), etc., allowing students to form interdisciplinary knowledge and skills. The peculiarity of studying is the possibility of having an internship not only in France but also abroad. Upon graduation, trainees will be able to work in project design and implementation, to hold a position of trainer or project manager in the field of "education for health and sustainable development".

The basis for the vision of ESD in Russian education was mainly the ecological concept and the study of environmental problems as "the initial stage of formation of a new systemic and holistic model of education for sustainable development". [4]. Currently, "the model of ESD as forward-looking education, interpretation of education based on the concept of "security through sustainable development", the concept of globalization of education and different forms of global education are being added to the environmental component of ESD, and other models of education will be synthesized in the future. Educational Master's programs in the field of SD are implemented, as well as in France, in the fields of economics, management, biological sciences (ecology), social sciences, etc. Here are some examples of Master's programs in Russian universities:

- "World Economy" within the specialization "Global Problems and Sustainable Development" (High School of Economics);

- "Economics of Sustainable Development". (Peoples' Friendship University of Russia);

- "Sustainable Development and Strategic Management in the Energy Sector" (Moscow State Institute of International Relations);

- "Talent Management for Sustainable Development" (Russian State University for the Humanities);

- "Geo-Ecological Bases of Sustainable Development" (Moscow State University).

Within the training direction 44.04.01 "Pedagogical Education" in Russian universities, the programs related to ecological education are implemented more often. For example, the Pedagogical Master's program "Technologies of Geographical Education and Environmental Education" at the Southern Federal University. The program combines universal teacher education with an advanced professional specialization in geography and ecology. The following are some examples of special disciplines included in the educational program and directly related to SD and ESD: "Basics of Territorial Sustainable Development" and "Social Ecology, Environmental Education and Enlightenment". Other examples of pedagogical Master courses are "Supplementary Environmental Education" at the Russian State Pedagogical University and "Environmental Education" at the Moscow Pedagogical State University.

\section{Conclusion}

In the modern period, there are qualitative changes in the development of higher teacher education in the direction of fundamentalization of education, practice-oriented education, technologization of education, individualization, variability of education, etc. However, despite the rather long existence, the idea of "education for sustainable development" remains an innovative guideline for improving the content of teacher education. As the research has shown, as a result of continuous modernization of higher pedagogical education in RF and in France at the beginning of XXI century organizational and pedagogical conditions in Master's education for successful implementation of sustainable development ideas have been created.

The basis of the modern vision of "education for sustainable development" is mainly the "environmental concept and model of education, which considers principles and goals of the modern model of sustainable development.

It is important, by improving the quality of teacher education through the development of master's education, to develop a system of training and professional development of teachers of different profiles, including subject teachers, teachers-psychologists, managers, organizers 
of children's and youth movement, educators, heads of clubs, studios, technical sections, etc. It is necessary to preserve and improve the experience of teacher training in different types of educational institutions.

The reported study was funded by RFBR, project number 19-313-90023

\section{References}

1. The Bologna Process in Russia: History and Modernity. ERASMUS+ National Office in Russia (Moscow, 2017)

2. B.L. Wolfson, Problems of modern education 2, 88 (2012)

3. E.N. Dzyatkovskaya, Modern pedagogical education 11, 16 (2019)

4. K.M. Alilova, South of Russia: ecology, development 11(3), 255 (2016)

5. E.I. Brazhnik, O.G. Lavrentieva, L.I. Lebedeva, Master's education in the system of university education in France and Russia (SPb, Publishing house HSPU, 2010)

6. N.F. Radionova, Modern research of actual problems of professional activity and teacher training (SPb, Publishing house «Svoe izdatelstvo», 2019)

7. T.N. Gavrilyeva, Vysshee obrazovanie v Rossii = Higher Education in Russia 27(7), 52 (2018)

8. V.A. Grachev, Education for sustainable development in Russia: problems and prospects (Moscow, 2017)

9. N.B. Kirillova, Higher Education in Russia 12, 66 (2010)

10. N.E. Gordienko, Professionalism and competence in the system of higher pedagogical education in France (Kolomna, 2013)

11. C. Becchetti-Bizot, G. Houzel, F. Taddei, Vers une société apprenante. Rapport sur la recherche et développement de l'éducation tout au long de la vie. Ministère de l'Éducation nationale, de l'Enseignement supérieur et de la Recherche (2017)

12. S.V. Zakharova, L.G. Tarshis, M.Yu. Mamontova, Int. Res. J. 11(101), 116 (2020) 